\section{Training in Industry}

Before the Second World War the amount of systematic training in British industry to fit industrial workers for their jobs was so small that it could be said to be almost non-existent. Since the War more and more firms have come to realize that traditional rule-of-thumb methods are costly, wasteful and inefficient and have done much to put their houses in order. To help all who are interested the Institute of Personnel Management is publishing a series of broadsheets which will cover various aspects of education in industry. The first of these, by E. Tegla Davies, education officer of Cadbury Bros., Ltd., provides an introduction to the scope and general principles of industrial training. The broadsheet describes the duties of an industrial education officer as well as the forms and techniques of industrial training. There is also a very useful bibliography. Other broadsheets in the series will deal with the training of unskilled or semi-skilled operatives, apprentices, clerical workers, supervisors and management. Further information can be obtained from the Institute of Personnel Management, Management House, Hill Street, London, W.1.

\section{Field Studies in Scotland}

THe Scottish Field Studies Association has arranged another interesting series of courses for 1957. Most of these will be held at the Garth Field Studies Centre in Perthshire, where the Association is able to share a magnificently situated youth hostel. Colin Murdoch, well known in Scotland for his broadcasts on natural history, will lead courses on ornithology and general field studies, and Dr. Joy Tivy will introduce beginners to geographical field studies. Other courses at Garth will be concerned with grasses, sedges and rushes; plant ecology; and mosses and liverworts. A longer course in nature study for teachers will be held at Dalguise House, Dunkeld, Perthshire, and will be led by Dr. John Smyth. Opportunities for geologists are provided at Lamlash, Isle of Arran, different courses being conducted by John Ashford and Dr. Norman Holgate. Further information can be obtained from 3 Woodend Drive, Glasgow, W.3.

\section{Forest Research-Products and Pathology}

The report of the Forest Products Research Board for 1955 (Department of Scientific and Industrial Research. Pp. vii $+69+8$ plates. London : H.M. Stationery Office, 1956) says that during the year there was little change in the general direction of the work of that laboratory, many inquiries being received and the volume of advisory and short-term work showing no decrease. The work for the Forestry Commission on the testing and evaluation of homegrown species has increased, but the report states that since the plantations are still immature the tests, though of interest, will continue for some years to be in their exploratory stages. The major commitments of testing and assessing new Colonial timbers and the important question of timber identification have engaged all sections, involving the co-operation of the forest botanist and the wood anatomist. Important work in this connexion has been carried out with dipterocarp timber from south-east Asia and a research bulletin has been published on Meranti, Seraya and allied timbers from the region. Two industrial surveys have been undertaken, one in connexion with the woods used for musical instruments and the other on the railway wagon and coachbuilding trade. Seasoning and testing of timber structures and research into plywood bending have continued. A special report has also been issued on laminated timber construction.

The first Bulletin on Forest Pathology in New Zealand (New Zealand Forest Service. Pp. vi $+62+$ 12 plates. Wellington: Government Printer, 1955) by J. J. de Gryse deals with the economic importance. of insects and disease in the forests of the Dominion. There are two types of forests in New Zealand, the indigenous forests of sub-tropic and sub-antarctic; types, and the large exotic conifer plantings. The study of both types and their relations and bearing on each other, which led to the present research, was. due to the appearance of two insects : a Sirex which. had been known in New Zealand for 25 years, during which it had been harmless until about 1948, when it increased in numbers and commenced an attack lasting three years, only to be followed by a plague of looper caterpillars in 1951-52. The attacks of these two during this period on the exotic pine were very heavy and threatened an area of 10,000 acres. of valuable forest.

\section{Meteorology in the International Geophysical Year}

ThE World Meteorological Organization has pub. lished a general survey of the meteorological programme for the International Geophysical Year. This booklet (pp. vii + 112. Geneva: World Meteorological Organization, 1956. 10 francs) gives a full statement of the aims of the meteorological plan and a history of its development in collaboration between the Comité Spécial pour l'Année Géophysique Internationale and the World Meteorological Organization. A very full commentary on the reasons for every aspect of the plan is given with remarks on the urgent work still to be done if technical needs are to be met. The organization appears to be most complete for the Antarctic, where there will be some eighteen stations in operation, transmitting their observations to the Weather Control at Little America on the Ross ice shelf. An important part of the book deals with the collection and distribution of the observations. 'The observations will be entered on special forms, illustrated in the book, and sent to the Meteorological Data Centre in the World Meteorological Organization Secretariat, where they will be reproduced on microcards for sale at cost price.

\section{Thunderstorms and Sporadic E-layer lonization}

THE occurrence of reflecting layers in an erratic manner, that is, not in accordance with the normal diumal variation in the ionosphere, has been known for many years. C. T. R. Wilson suggested thirty years ago that these layers might be produced by thunderstorms, either by the shooting upwards of electrons from the thundercloud or by electric dis. charges in the ionosphere released in the very thin air by the electric field of the storm. Since then some evidence has been for Wilson's hypothesis and some, mainly statistical, against it. Now an account has appeared, by R. G. Rastagi (Indian J. Meteor. Geophys., 8, 43; 1957), of six isolated thunderstorms at Ahmedabad, India, over which a sporadic $E$ reflecting layer formed in the ionosphere. The records of sporadic $E$ reflexions are given in detail. The sporadic $E$-layer formed at heights of $100-$ $140 \mathrm{~km}$. within half an hour of the onset of the storm. The storms were all outside the monsoon season. Storms during the monsoon period are at a lower 